\title{
Central Nervous System Lupus
}

National Cancer Institute

\section{Source}

National Cancer Institute. Central Nervous System Lupus. NCI Thesaurus. Code

C116919.

Inflammation that includes the brain, spinal cord and surrounding tissues secondary to systemic lupus erythematosus (SLE); it is associated with neurological and/or psychiatric features. 